\title{
KINERJA GURU MADRASAH DAN GURU PENDIDIKAN AGAMA ISLAM PASCA SERTIFIKASI DI SUMATERA SELATAN
}

\author{
Nyayu Khodijah \\ FT IAIN Raden Fatah \\ email: nyayu_dd@yahoo.com
}

\begin{abstract}
Abstrak: Penelitian ini bertujuan mengetahui kinerja guru setelah memperoleh tunjangan profesional. Penelitian ini menggunakan metode deskriptif-komparatif. Sampel adalah guru-guru madrasah dan Pendidikan Agama Islam di Palembang dan Banyuasin. Data dikumpulkan dengan menggunakan kuesioner, wawancara, dan dokumen, dan kemudian dianalisis secara kuantitatif dan kualitatif. Hasil penelitian menunjukkan bahwa tidak terdapat perbedaan dalam kinerja guru setelah menerima tunjangan professional (1) dalam aspek rencana pembelajaran, pelaksanaan, dan asesmen; (2) antara mereka yang tinggal di daerah pedesaan dan di daerah perkotaan; dan (3) antara mereka yang lulus melalui portofolio dan melalui PLPG.
\end{abstract}

Kata Kunci: kinerja guru, program sertifikasi guru

\section{ISLAMIC SCHOOL AND ISLAM RELIGION TEACHERS' PERFORMANCE AFTER THE CERTIFICATION PROGRAM IN SOUTH SUMATERA}

\begin{abstract}
This research aimed at figuring out the teachers' performance after they received their professional benefit. This research applied the descriptive-comparative method. The sample was Islamic school and Islam Religion teachers in Palembang and Banyuasin. The data were collected using questionnaires, interview, and documentation, and then analyzed quantitatively and qualitatively. The findings showed that there was no difference in the teachers' performance after they received their professsional benefit (1) in the aspects of lesson planning, implementation, and assessment; (2) between those living in urban and rural areas; and (3) between those who pass the certification program through portfolio and professional training.
\end{abstract}

Keywords: teacher's performance, teacher certification program

\section{PENDAHULUAN}

Guru memegang peran utama dalam pendidikan, khususnya pendidikan yang diselenggarakan secara formal di sekolah/madrasah. Guru sangat menentukan keberhasilan peserta didik, terutama dalam kaitannya dengan proses pembelajaran. Guru merupakan komponen yang paling berpengaruh terhadap terciptanya proses dan hasil pendidikan yang berkualitas. Oleh karena itu, upaya perbaikan apapun yang dilakukan untuk meningkatkan kualitas pendidikan tidak akan memberikan sumbangan yang signifikan tanpa didukung oleh guru yang profesional dan berkualitas. Begitu pentingnya peran guru dalam proses pendidkan, maka seorang guru dituntut untuk selalu meningkatkan kemampuan dan kinerjanya sebagai tenaga yang bermartabat dan profesional.
Menyadari pentingnya peran guru dalam pendidikan, berbagai upaya peningkatan kualitas guru telah dilakukan pemerintah, di antaranya adalah melalui program sertifikasi guru. Namun, program sertifikasi tersebut yang sejatinya adalah untuk meningkatkan kompetensi yang ditunjukkan pada peningkatan kinerja guru ternyata tidak sesuai dengan yang diharapkan, guru yang telah lolos sertifikasi ternyata tidak menunjukkan kompetensi yang signifikan (Son, 2009:28). Dalam pidato pengukuhan guru besar pada FKIP Universitas Sebelas Maret Solo, Baedhowi motivasi para guru mengikuti sertifikasi umumnya terkait aspek finansial, yaitu segera mendapat tunjangan profesi (Son, 2009:28). Motivasi yang sama ditemukan oleh Direktorat Jenderal PMPTK Kemendiknas ketika melakukan kajian serupa di Propinsi 
Sumatera Barat, Jawa Timur, Jawa Tengah, Sulawesi Selatan, dan Nusa Tenggara Barat pada tahun 2008. Hasilnya menunjukkan, walaupun alasan mereka bervariasi, secara umum motivasi mereka mengikuti sertifikasi ialah finansial. Tujuan utama sertifikasi untuk mewujudkan kompetensi guru tampaknya masih disikapi sebagai wacana (Son, 2009:28).

Kenyataan tersebut, menunjukkan bahwa sertifikasi guru tidaklah cukup sebagai upaya mewujudkan dan meningkatkan kompetensi dan kinerja guru. Meski telah dinyatakan lulus sertifikasi dan telah menerima tunjangan profesi, bukan berarti guru telah memiliki kompetensi dan menunjukkan kinerja yang dipersyaratkan undang-undang. Untuk mewujudkan guru yang benar-benar profesional, pasca sertifikasi perlu adanya upaya sistematis dan sinergis dan berkesinambungan yang menjamin guru tetap profesional. Berdasarkan uraian di atas, perlu dikaji lebih lanjut tentang dampak sertifikasi. Salah satunya adalah mengkaji kinerja guru setelah memperoleh tunjangan profesional melalui program sertifikasi guru.

Secara kebahasaan, kinerja merupakan terjemahan dari kata performance (bahasa Inggris) yang berasal dari kata to perform, yang antara lain berarti: (1) menjalankan atau melakukan; (2) memenuhi atau menjalankan kewajiban suatu nazar; (3) menggambarkan suatu karakter dalam suatu permainan; (4) menggambarkannya dengan suara atau alat musik; (5) melaksanakan atau menyempurnakan tanggung jawab; (6) melakukan suatu kegiatan dalam suatu permainan; (7) memainkan (pertunjukan) musik; dan (8) melakukan sesuatu yang diharapkan oleh seseorang atau mesin (Prawirosentono 1999:1-2). Sementara secara konseptual, kinerja diartikan sebagai suatu pencapaian persyaratan pekerjaan tertentu yang akhirnya secara langsung dapat tercermin dari output yang dihasilkan baik kuantitas maupun kualitasnya (Simamora, 2000:423). Sejalan dengan ini, Bernardin dan Russel (2002:239) mendefinisikan kinerja sebagai catatan tentang hasilhasil yang diperoleh dari fungsi-fungsi pekerjaan atau kegiatan tertentu selama kurun waktu tertentu.
Menurut August W. Smith, seperti yang dikutip oleh Sedarmayanti (1995:50), kinerja adalah "output drive processes, human or otherwise'. Maksudnya, kinerja merupakan hasil atau keluaran dari suatu proses. Menurut Prawirosentono (1999:2), performance atau kinerja adalah hasil kerja yang dapat dicapai oleh seseorang atau sekelompok orang dalam suatu organisasi, sesuai dengan wewenang dan tanggung jawab masing-masing dalam rangka mencapai tujuan organisasi bersangkutan secara legal, tidak melanggar hukum dan sesuai dengan moral maupun etika. Sejalan dengan pengertian tersebut, Alamsyah dan Muslim (2006: 9) mendefinisikan kinerja sebagai "prestasi yang dicapai seseorang, sekelompok orang, atau lembaga berkaitan dengan posisi dan peran yang dimilikinya". Pengertian-pengertian kinerja di atas menunjukkan bahwa kinerja identik dengan prestasi kerja.

Simanjuntak (2005:103) membedakan antara kinerja individu dengan kinerja organisasi. Menurutnya, kinerja individu adalah tingkat pencapaian atau hasil kerja seseorang dari sasaran yang harus dicapai atau tugas yang harus dilaksanakan dalam kurun waktu tertentu, sedangkan kinerja organisasi adalah tingkat pencapaian sasaran atau tujuan yang harus dicapai oleh organisasi tersebut dalam kurun waktu tertentu. Khusus tentang kinerja individu, menurut Mangkunegara (2001:67), "kinerja adalah hasil kerja secara kualitas dan kuantitas yang dicapai oleh seseorang dalam melaksanakan tugasnya sesuai dengan tanggung jawab yang diberikan kepadanya".

Sedarmayanti (1996:144) menyatakan bahwa "kinerja individu dapat dinilai dari apa yang dilakukan individu dalam kerjanya. Dengan kata lain, kinerja individu adalah bagaimana seseorang melaksanakan pekerjaannya atau unjuk kerja". Pernyataan unjuk kerja menunjukkan bahwa kinerja individu dapat dilihat melalui kesungguhan individu yang bersangkutan dalam melaksanakan tugas sesuai dengan pekerjaan yang dibebankan kepadanya dan sekaligus menjadi tanggung jawabnya. Dari definisi tersebut, dapat dikatakan bahwa kinerja merupakan unjuk kerja seseorang dalam 
mengerjakan suatu pekerjaan pada jangka waktu atau periode tertentu berdasarkan norma atau ukuran yang berlaku untuk pekerjaan itu. Dengan demikian, penilaian kinerja berdasarkan konsep ini didasarkan pada rincian tugas yang harus dilakukan dalam pekerjaan tersebut.

Untuk mengetahui apakah kinerja seorang guru sudah cukup optimal atau belum dapat dilihat dari berbagai indikator. Menurut Simamora (2000:423), indikator-indikator kinerja meliputi: (1) keputusan terhadap segala aturan yang ditetapkan organisasi; (2) dapat melaksanakan pekerjaan atau tugasnya tanpa kesalahan (atau dengan tingkat kesalahan yang paling rendah); dan (3) ketepatan dalam menjalankan tugas. Ukuran kinerja secara umum yang kemudian diterjemahkan ke dalam penilaian perilaku secara mendasar meliputi: (1) mutu kerja; (2) kuantitas kerja; (3) pengetahuan tentang pekerjaan; (4) pendapat atau pernyataan yang disampaikan; (5) keputusan yang diambil; (6) perencanaan kerja; dan 7) daerah organisasi kerja. Sedang kinerja untuk tenaga guru umumnya dapat diukur melalui: (1) kemampuan membuat perencanaan; (2) kemampuan melaksanakan rencana pembelajaran; (3) kemampuan melaksanakan evaluasi; dan (4) kemampuan menindaklanjuti hasil evaluasi.

Moh. Uzer Usman (2006:10-19) mengemukakan beberapa indikator kinerja guru seperti berikut. Pertama, kemampuan merencanakan belajar mengajar, yang meliputi: (1) menguasai garis-garis besar penyelenggaraan pendidikan, (2) menyesuaikan analisa materi pelajaran, (3) menyusun program semester, (4) menyusun program atau pembelajaran. Kedua, kemampuan melaksanakan kegiatan belajar mengajar, yang meliputi: (1) tahap pra instruksional, (2) tahap instruksional, (3) tahap evaluasi dan tidak lanjut. Keempat, kemampuan mengevaluasi, yang meliputi: (1) evaluasi normatif, (2) evaluasi formatif, (3) laporan hasil evaluasi, dan d) pelaksanaan program perbaikan dan pengayaan. Ditjen Dikdasmen (2000:89) mengemukakan enam unsur yang merupakan indikator kinerja guru, yaitu: (1) penguasaan landasan kependidikan, (2) penguasaan bahan pembelajaran, (3) pengelolaan proses belajar mengajar, (4) penggunaan alat pelajaran, (5) pemahaman metode penelitian untuk peningkatan pembelajaran, dan (6) pemahaman administrasi sekolah. Schacter (2000:14) membagi indikator kinerja guru dalam tiga bagian, yaitu: (1) keterampilan, pengetahuan, dan tanggung jawab guru, (2) pencapaian prestasi siswa pada level kelas, dan (3) pencapaian prestasi sekolah.

Berdasarkan uraian di atas, dapat disimpulkan bahwa kinerja guru adalah hasil yang dicapai oleh guru dalam pelaksanaan tugas mengajar yang bermutu. Dalam penelitian ini, kinerja guru dimaksudkan sebagai unjuk kerja dalam pelaksanaan tugas mengajar dengan empat indikator, yaitu: (1) kinerja dalam perencanaan pembelajaran, (2) kinerja dalam pelaksanaan pembelajaran, (3) kinerja dalam penilaian pembelajaran, dan (4) kinerja dalam pengembangan profesi. Aspek-aspek dalam keempat indikator inilah yang dijadikan standar minimum kinerja guru dalam penelitian ini.

Penelitian ini bertujuan untuk mengetahui kinerja guru madrasah dan guru Pendidikan Agama Islam (PAI) di sekolah umum setelah memperoleh tunjangan profesional melalui program sertifikasi guru. Selain itu, penelitian ini juga bertujuan untuk mengetahui perbedaan kinerja pasca sertifikasi antara guru madrasah dan guru PAI di sekolah umum, antara guru yang tinggal di kota dan yang tinggal di desa, serta antara guru yang lulus sertifikasi melalui jalur portofolio dan PLPG.

\section{METODE}

Penelitian ini menggunakan pendekatan mixed methods (Creswell, 2008:552), yaitu penggunaan pendekatan baik kuantitatif maupun kualitatif dalam satu penelitian guna memahami masalah penelitian. Desain mixed methods yang digunakan adalah desain trianggulasi. Creswell (2008:62) mengemukakan bahwa desain ini digunakan untuk membandingkan data kuantitatif dengan temuan kualitatif atau untuk memvalidasi atau memperluas hasil kuantitatif dengan data kualitatif. Metode penelitian yang digunakan adalah penelitian deskriptif komparatif, yaitu menggambarkan fenomena yang ada disertai dengan upaya untuk 
membandingkan berdasarkan keadaan yang mungkin mempengaruhi perbedaannya.

Lokasi penelitian adalah Kota Palembang dan Kabupaten Banyuasin. Populasi adalah guru yang mengajar di madrasah (MI, MTs, maupun di MA), dan guru Pendidikan Agama Islam (PAI) di sekolah umum (SD, SMP, maupun SMA) di lokasi penelitian yang sudah lulus sertifikasi dan mendapatkan tunjangan profesi. Berdasarkan data tahun 2010 yang diperoleh dari Fakultas Tarbiyah IAIN Raden Fatah Palembang sebagai penyelenggara kegiatan sertifikasi guru di propinsi Sumatera Selatan, jumlah guru madrasah dan guru PAI yang sudah lulus sertifikasi pada tahun 2007 dan 2008 serta mendapatkan tunjangan profesi pada tahun berikutnya di Kota Palembang berjumlah 277 orang dan di Kabupaten Banyuasin berjumlah 53 orang, sehingga jumlah keseluruhan populasi adalah sebanyak 330 orang.

Teknik pengambilan sampel yang digunakan adalah multistage sampling dengan cara proportional probability. Pengambilan sampel dilakukan dua tahapan sebagai berikut: Pertama, pemilihan sampel kota/kabupaten, dilakukan secara purposive dan dipilih kota Palembang dan Kabupaten Banyuasin dengan pertimbangan mewakili kondisi perkotaan dan pedesaan. Kedua, pemilihan sampel responden, baik responden guru madrasah dan guru PAI. Dalam hal ini digunakan teknik random sampling sebesar $\pm 12,5 \%$ dari total populasi. Sehingga jumlah total sampel responden penelitian ini adalah 41 orang, dengan rincian 26 orang dari kota Palembang dan 15 orang dari kabupaten Musi Banyuasin.

Teknik pengumpulan data yang digunakan meliputi: kuesioner, wawancara, dan telaah dokumentasi. Kuesioner digunakan untuk menggali data tentang kinerja guru setelah lulus sertifikasi dan memperoleh tunjangan profesi. Kuesioner disusun sendiri oleh peneliti berdasarkan standar kinerja yang berlaku dengan indikator-indikator: kinerja dalam perencanaan pembelajaran, kinerja dalam pelaksanaan pembelajaran, kinerja dalam penilaian pembelajaran, dan kinerja dalam pengembangan profesi.
Guna memastikan validitas kuesioner yang digunakan, sebelum dianalisis data yang diperoleh terlebih dahulu dianalisis validitasnya. Kelemahan utama teknik kuesioner adalah seringkali responden memberikan jawaban yang tidak jujur. Untuk mengatasi hal itu, kuesioner dibuat anonim, diberi nama angket kejujuran, dan pada petunjuk pengisian ditekankan pada penghargaan atas kejujuran jawaban yang diberikan.

Wawancara dilakukan sebagai trianggulasi data yang diperoleh melalui kuesioner. Wawancara juga ditujukan untuk menggali data tentang faktor-faktor penghambat dan pendukung kinerja guru berdasarkan penilaian kepala madrasah/sekolah. Selain melalui wawancara, trianggulasi data juga digali melalui telaah dokumen guna mengumpulkan data tentang kinerja guru dalam perencanaan pembelajaran, khususnya dalam penyusunan Rencana Pelaksanaan Pembelajaran (RPP).

Analisis data dilakukan secara kuantitatif dan kualitatif sesuai dengan jenis data yang dikumpulkan. Data kuantitatif yang dikumpulkan melalui kuesioner dianalisis secara kuantitatif dengan teknik statistik distribusi frekuensi dan persentase, sedang data hasil wawancara dan telaah dokumentasi dianalisis secara kualitatif dengan teknik analisis deskriptif kualitatif dari Miles dan Huberman.

\section{HASIL DAN PEMBAHASAN Hasil Kuesioner}

Hasil pengumpulan data melalui kuesioner menunjukkan bahwa secara umum kinerja guru setelah lulus sertifikasi dan memperoleh tunjangan profesi, baik guru madrasah maupun guru PAI, masih di bawah standar minimum kinerja. Hal ini terlihat dari skor ratarata kinerja guru sebesar 95,02, median 99, modus 99, dengan rentangan skor antara 66 111 dalam rentang teoritik $0-117$.

Berdasarkan skor persentil dari masingmasing responden, dilakukan kategorisasi kinerja guru dengan perhitungan: skor maksimal $=117$, skor minimal $=0$, rata-rata $=95,02$, dan deviasi standar $=13,07$. Dengan demikian, batasan kategori tinggi adalah: Rata-rata +1 
Deviasi Standar $=95,02+13,07=108,09$, sedang batasan kategori rendah adalah: Ratarata -1 Deviasi Standar $=95,02-13,07=$ 81,95 . Sehingga dapat diketahui bahwa secara umum rata-rata kinerja guru $(95,02)$ setelah lulus sertifikasi dan memperoleh tunjangan profesi berada pada kategori sedang.

Selanjutnya dilakukan pengolahan data dengan menggunakan teknik persentase untuk masing-masing kategori. Hasilnya, dari 41 guru yang menjadi responden, 30 orang $(73,17 \%)$ menunjukkan kinerja yang sedang, 8 orang $(19,51 \%)$ menunjukkan kinerja yang rendah, dan hanya 3 orang $(7,32 \%)$ menunjukkan kinerja yang tinggi. Dengan demikian, dapat dikatakan bahwa kinerja sebagian besar guru pasca sertifikasi masih di bawah standar, karena sebagian besar guru (lebih dari 70\%) masih menunjukkan kinerja yang sedang, bahkan guru yang menunjukkan kinerja yang rendah persentasenya juga cukup signifikan, hampir mencapai $20 \%$. Sementara guru yang menunjukkan kinerja yang tinggi kurang dari $10 \%$. Ini berarti bahwa meski telah mengikuti sertifikasi dan mendapatkan tunjangan profesi tidak membuat sebagian besar guru berupaya meningkatkan kinerjanya.

Secara khusus, dilihat dari masingmasing indikator, hasil analisis data kinerja guru menunjukkan sebagai berikut.

\section{Kinerja Guru dalam Perencanaan Pembe- lajaran}

Hasil pengumpulan data melalui kuesioner menunjukkan bahwa kinerja guru dalam perencanaan pembelajaran masih di bawah standar minimum kinerja. Hal ini terlihat dari skor rata-rata kinerja guru sebesar 25,39, median 27 , modus 28 , dengan rentangan skor antara 16 - 30 dalam rentang teoritik $0-30$.

Berdasarkan skor persentil dari masingmasing responden, dilakukan kategorisasi kinerja guru dengan perhitungan: skor maksimal $=30$, skor minimal $=0$, rata-rata $=25,39$, dan deviasi standar $=3,67$. Dengan demikian, batasan kategori tinggi adalah: Rata-rata +1 Deviasi Standar $=25,39+3,67=29,06$, sedang batasan kategori rendah adalah: Rata-rata - 1
Deviasi Standar $=25,39-3,67=21,72$ sehingga dapat diketahui bahwa rata-rata kinerja guru $(25,39)$ dalam perencanaan pembelajaran berada pada kategori sedang.

Selanjutnya dilakukan pengolahan data dengan menggunakan teknik persentase untuk masing-masing kategori. Hasilnya, 33 orang (80,49\%) menunjukkan kinerja yang sedang, 7 orang $(17,07 \%)$ menunjukkan kinerja yang rendah, dan hanya 1 orang $(2,44 \%)$ menunjukkan kinerja yang tinggi. Dengan demikian, dapat dikatakan bahwa dalam melaksanakan perencanaan pembelajaran, kinerja sebagian besar guru pasca sertifikasi masih di bawah standar, karena sebagian besar guru (lebih dari 80\%) masih menunjukkan kinerja yang sedang, bahkan guru yang menunjukkan kinerja yang rendah persentasenya juga cukup signifikan (lebih dari 17\%). Sementara guru yang menunjukkan kinerja yang tinggi masih kurang dari $3 \%$. Ini berarti bahwa meski telah mengikuti sertifikasi dan mendapatkan tunjangan profesi tidak membuat sebagian besar guru berupaya meningkatkan kinerjanya dalam perencanaan pembelajaran.

\section{Kinerja Guru dalam Pelaksanaan Pembe- lajaran}

Hasil pengumpulan data melalui kuesioner menunjukkan bahwa kinerja guru dalam pelaksanaan pembelajaran masih di bawah standar minimum kinerja. Hal ini terlihat dari skor rata-rata kinerja guru sebesar 43,20, median 44, modus 49, dengan rentangan skor antara 33 - 50 dalam rentang teoritik $0-51$.

Berdasarkan skor persentil dari masingmasing responden, dilakukan kategorisasi kinerja guru dengan perhitungan: skor maksimal $=51$, skor minimal $=0$, rata-rata $=43,20$, dan deviasi standar $=5,49$. Dengan demikian, batasan kategori tinggi adalah: Rata-rata +1 Deviasi Standar $=43,20+5,49=48,69$, sedang batasan kategori rendah adalah: Rata-rata - 1 Deviasi Standar $=43,20-5,49=37,71$. Sehingga dapat diketahui bahwa rata-rata kinerja guru $(43,20)$ dalam pelaksanaan pembelajaran berada pada kategori sedang. 
Selanjutnya, dilakukan pengolahan data dengan menggunakan teknik persentase untuk masing-masing kategori. Hasilnya, 23 orang $(56,10 \%)$ menunjukkan kinerja yang sedang, 10 orang $(24,39 \%)$ menunjukkan kinerja yang tinggi, dan 8 orang $(19,51 \%)$ menunjukkan kinerja yang rendah. Dengan demikian, dapat dikatakan bahwa dalam melaksanakan proses pembelajaran, kinerja sebagian besar guru pasca sertifikasi masih di bawah standar, karena sebagian besar guru (lebih dari 50\%) masih menunjukkan kinerja yang sedang, bahkan guru yang menunjukkan kinerja yang rendah persentasenya cukup signifikan (mendekati 20\%). Sementara guru yang menunjukkan kinerja yang tinggi masih kurang dari $25 \%$. Ini berarti bahwa meski telah mengikuti sertifikasi dan mendapatkan tunjangan profesi tidak membuat sebagian besar guru berupaya meningkatkan kinerjanya dalam pelaksanaan pembelajaran.

\section{Kinerja Guru dalam Penilaian Pembelajaran}

Hasil pengumpulan data melalui kuesioner menunjukkan bahwa kinerja guru dalam penilaian pembelajaran masih di bawah standar minimum kinerja. Hal ini terlihat dari skor ratarata kinerja guru sebesar 23,12, median 23, modus 28 , dengan rentangan skor antara 15 30 dalam rentang teoritik $0-30$.

Berdasarkan skor persentil dari masingmasing responden, dilakukan kategorisasi kinerja guru dengan perhitungan: skor maksimal $=30$, skor minimal $=0$, rata-rata $=23,12$, dan deviasi standar $=4,44$. Dengan demikian, batasan kategori tinggi adalah: Rata-rata +1 Deviasi Standar $=23,12+4,44=27,56$, sedang batasan kategori rendah adalah: Rata-rata - 1 Deviasi Standar $=23,12-4,44=18,68$ sehingga dapat diketahui bahwa rata-rata kinerja guru $(23,12)$ dalam penilaian pembelajaran berada pada kategori sedang.

Selanjutnya dilakukan pengolahan data dengan menggunakan teknik persentase untuk masing-masing kategori. Hasilnya, 23 orang (56,10\%) menunjukkan kinerja yang sedang, 12 orang $(29,27 \%)$ menunjukkan kinerja yang tinggi, dan 6 orang $(14,63 \%)$ menunjukkan kinerja yang rendah. Dengan demikian, dapat dikatakan bahwa dalam penilaian pembelajaran, kinerja sebagian besar guru pasca sertifikasi masih di bawah standar, karena sebagian besar guru (lebih dari 50\%) masih menunjukkan kinerja yang sedang, bahkan guru yang menunjukkan kinerja yang rendah persentasenya cukup signifikan (mendekati 15\%). Sementara guru yang menunjukkan kinerja yang tinggi masih kurang dari 30\%. Ini berarti bahwa meski telah mengikuti sertifikasi dan mendapatkan tunjangan profesi tidak membuat sebagian besar guru berupaya meningkatkan kinerjanya dalam penilaian pembelajaran.

\section{Kinerja Guru dalam Pengembangan Profesi}

Hasil pengumpulan data melalui kuesioner menunjukkan bahwa kinerja guru dalam pengembangan profesi masih di bawah standar minimum kinerja. Hal ini terlihat dari skor ratarata kinerja guru sebesar 3,32, median 3, modus 3 , dengan rentangan skor antara $0-6$ dalam rentang teoritik $0-6$.

Berdasarkan skor persentil dari masingmasing responden, dilakukan kategorisasi kinerja guru dengan perhitungan: skor maksimal $=6$, skor minimal $=0$, rata-rata $=3,32$, dan deviasi standar $=1,44$. Dengan demikian, batasan kategori tinggi adalah: Rata-rata +1 Deviasi Standar $=3,32+1,44=4,76$, sedang batasan kategori rendah adalah: Rata-rata - 1 Deviasi Standar $=3,32-1,44=1,88$. Sehingga dapat diketahui bahwa rata-rata kinerja guru $(3,32)$ dalam pengembangan profesi berada pada kategori sedang.

Selanjutnya dilakukan pengolahan data dengan menggunakan teknik persentase untuk masing-masing kategori. Hasilnya, 31 orang $(75,61 \%)$ menunjukkan kinerja yang sedang, 6 orang $(14,63 \%)$ menunjukkan kinerja yang tinggi, dan 4 orang $(9,76 \%)$ menunjukkan kinerja yang rendah. Dengan demikian, dapat dikatakan bahwa dalam pengembangan profesi, kinerja sebagian besar guru pasca sertifikasi masih di bawah standar, karena sebagian besar guru (lebih dari 75\%) masih menunjukkan kinerja yang sedang, bahkan ada yang menunjukkan kinerja yang rendah (mendekati 10\%). Sementara guru yang menunjukkan kinerja 
yang tinggi kurang dari $15 \%$. Ini berarti bahwa meski telah mengikuti sertifikasi dan mendapatkan tunjangan profesi tidak membuat sebagian besar guru berupaya meningkatkan kinerjanya dalam pengembangan profesi.

Berikutnya adalah melihat perbedaan kinerja berdasarkan perbedaan tempat tugas (madrasah atau guru PAI di sekolah umum), perbedaan lingkungan sosial budaya (di lingkungan perkotaan atau pedesaan), dan perbedaan jalur sertifikasi (jalur portofolio atau PLPG), maka diperoleh hasil penelitian berikut.

\section{Perbedaan Kinerja Guru Madrasah dan Kinerja Guru PAI}

Dilihat dari mean (rata-rata) skor kinerja guru, diketahui bahwa rata-rata kinerja guru PAI $(97,60)$ lebih tinggi dibandingkan dengan rata-rata kinerja guru madrasah $(93,50)$. Hasil uji-t terhadap perbedaan skor kinerja guru madrasah dan guru PAI diperoleh harga $\mathrm{t}=-0,967$ dengan taraf signifikansi $=0,339$. Dengan demikian, tidak ditemukan perbedaan yang signifikan kinerja antara guru yang bertugas di madrasah dengan guru PAI yang bertugas di sekolah umum. Dengan kata lain, perbedaan tempat tugas guru tidak menyebabkan perbedaan kinerja mereka pasca sertifikasi dan mendapatkan tunjangan profesi.

\section{Perbedaan Kinerja Guru yang Tinggal di Perkotaan dan yang Tinggal di Pedesaan}

Dilihat dari mean (rata-rata) skor kinerja guru, diketahui bahwa rata-rata kinerja guru yang tinggal di perkotaan $(96,96)$ lebih tinggi dibandingkan dengan rata-rata kinerja guru yang tinggal di pedesaan $(91,60)$. Hasil uji-t terhadap perbedaan skor kinerja guru yang tinggal di perkotaan dan yang tinggal di pedesaan diperoleh harga $t=1,276$ dengan taraf signifikansi $=0,209$. Dengan demikian, tidak ditemukan perbedaan yang signifikan kinerja antara guru yang tinggal di perkotaan dan yang tinggal di pedesaan. Dengan kata lain, perbedaan lingkungan sosial budaya guru tidak menyebabkan perbedaan kinerja mereka pasca sertifikasi dan mendapatkan tunjangan profesi.

\section{Perbedaan Kinerja Guru yang ulus Sertifikasi melalui Jalur Portofolio dan Jalur PLPG}

Dilihat dari mean (rata-rata) skor kinerja guru, diketahui bahwa rata-rata kinerja guru yang lulus melalui jalur PLPG $(96,93)$ lebih tinggi dibandingkan dengan rata-rata kinerja guru yang lulus melalui jalur portofolio $(93,88)$. Hasil uji-t terhadap perbedaan skor kinerja guru yang lulus sertifikasi melalui jalur portofolio dan jalur PLPG diperoleh harga $t=0,716$ dengan taraf signifikansi $=0,479$. Dengan demikian, tidak ditemukan perbedaan yang signifikan kinerja antara guru yang lulus sertifikasi melalui jalur portofolio dan jalur PLPG. Kinerja guru yang lulus sertifikasi melalui jalur portofolio tidak lebih baik dibandingkan dengan kinerja guru yang lulus melalui jalur PLPG, demikian pula sebaliknya. Dengan kata lain, perbedaan jalur kelulusan dalam sertifikasi tidak menyebabkan perbedaan kinerja guru pasca sertifikasi dan mendapatkan tunjangan profesi.

\section{Hasil Wawancara \\ Penilaian Kepala Madrasah/Sekolah terhadap Kinerja Guru Pasca Sertifikasi}

Berdasarkan hasil wawancara dengan kepala madrasah/sekolah, diketahui bahwa sebagian besar kepala madrasah/sekolah menilai kinerja guru yang sudah lulus sertifikasi sudah mendekati standar kinerja yang berlaku. Peningkatan kinerja yang dinilai sudah dicapai diantaranya adalah: (1) pada aspek perencanaan, guru telah mampu menyusun program tahunan, program semester, silabus, dan RPP, serta hasilnya sudah cukup lebih baik serta telah disusun lebih awal dari sebelumnya (Wawancara, 20 September 2010). Selain itu, RPP yang sebelumnya disusun untuk satu semester sekaligus, sekarang sudah dibuat pada setiap tatap muka (disesuaikan dengan kebutuhan) (Wawancara, 26 Agustus 2010), serta (2) pada aspek pelaksanaan pembelajaran, guru sudah menggunakan berbagai media/alat peraga (Wawancara, 20 September 2010). Meski demikian, tidak satupun dari responden kepala madrasah/sekolah yang menyatakan kinerja guru sudah mencapai kinerja yang optimal atau 
mencapai standar kinerja yang berlaku, bahkan ada yang menilainya hanya mendekati standar kinerja.

\section{Faktor Penghambat Peningkatan Kinerja Guru}

Berdasarkan hasil wawancara dengan kepala madrasah/sekolah, diketahui bahwa ada berbagai faktor penghambat peningkatan kinerja guru. Dalam perencanaan pembelajaran, faktor penghambat yang diduga adalah: (1) kurangnya sarana prasarana pendukung, seperti media pembelajaran(Wawancara, 20 September 2010), (2) untuk guru kelas terlalu banyak materi yang harus disiapkan (Wawancara, 20 September 2010), dan (3) sebagian guru masih kurang berkeinginan melakukan perubahan positif (Wawancara, 1 September 2010). Dalam pelaksanaan pembelajaran, faktor penghambat yang diduga adalah: (1) masih rendahnya kemampuan guru dalam menyusun RPP (Wawancara, 20 September 2010), (2) perbedaan karakteristik siswa yang menyulitkan guru (Wawancara, 1 September 2010), dan (3) kurangnya alokasi waktu yang tersedia (Wawancara, 25 Agustus 2010).

Dalam penilaian pembelajaran, faktor penghambat yang diduga adalah: (1) masih rendahnya kemampuan guru dalam melakukan penilaian (Wawancara, 25 Agustus 2010), terutama penilaian proses (Wawancara, 20 September 2010), dan (2) perbedaan karakteristik siswa yang menyulitkan guru (Wawancara, 1 September 2010). Dalam pengembangan profesi, faktor penghambat yang diduga adalah: (1) kurangnya akses informasi terbaru (Wawancara, 1 September 2010), karena berada di daerah terpencil (Wawancara, 20 September 2010), dan (2) kesibukan lain di luar kegiatan madrasah/sekolah (Wawancara, 1 September 2010).

\section{Faktor Pendukung Peningkatan Kinerja Guru}

Sebagaimana faktor penghambat, berdasarkan hasil wawancara dengan kepala madrasah/sekolah juga ditemukan berbagai faktor pendukung peningkatan kinerja guru. Dalam perencanaan pembelajaran, faktor pendukung yang diduga adalah: (1) adanya kemauan untuk maju sehingga mendorong guru tersebut berbuat lebih baik (Wawancara, 20 September 2010), (2) kerjasama yang baik antara guru dan kepala madrasah/sekolah (Wawancara, 25 Agustus 2010), dan (3) adanya supervisi yang dilakukan baik oleh kepala madrasah/sekolah maupun pengawas (Wawancara, 25 Agustus 2010). Dalam pelaksanaan pembelajaran, faktor pendukung yang diduga adalah: (1) pengalaman mengajar yang dimiliki oleh guru telah cukup lama (Wawancara, 20 September 2010), (2) kerjasama yang baik antara guru dan kepala madrasah/sekolah (Wawancara, 25 Agustus 2010).

Dalam penilaian pembelajaran, faktor pendukung yang diduga adalah: kerjasama yang baik antara guru dan kepala madrasah/sekolah (Wawancara, 20 September 2010). Dalam pengembangan profesi, faktor pendukung yang diduga adalah: (1) adanya kegiatan KKG, penataran, dan lain-lain yang diadakan oleh Kemendiknas maupun Kemenag (Wawancara, 20 September 2010), (2) adanya tunjangan profesi (Wawancara, 20 September 2010) yang berarti peningkatan kesejahteraan guru (Wawancara, 25 Agustus 2010), dan kerjasama yang baik antara guru dan kepala madrasah/sekolah (Wawancara, 25 Agustus 2010).

\section{Hasil Telaah Dokumen}

Telaah dokumen dilakukan untuk menilai kualitas perencanaan pembelajaran yang dilakukan oleh guru, khususnya dalam penyusunan RPP. Dalam hal ini, telaah dokumen dilakukan berdasarkan penilaian kepala madrasah/sekolah, dengan pertimbangan bahwa kepala sekolah adalah supervisor sekolah yang memiliki kemampuan melakukan pengawasan dan pengendalian untuk meningkatkan kinerja tenaga kependidikan. Standar yang digunakan adalah lembar penilaian RPP yang digunakan oleh para asesor sertifikasi guru dalam penilaian portofolio. Skor standar kualitas RPP adalah skor teoritik tertinggi, yaitu 40.

Dari hasil penilaian 13 orang kepala madrasah/sekolah terhadap 13 dokumen RPP yang disusun oleh guru yang telah lulus sertifikasi 
dan mendapatkan tunjangan profesi, diketahui bahwa: total nilai yang dicapai adalah: 456, sehingga rata-rata skor kualitas RPP adalah 456 : $13=35,08$. Dibandingkan dengan skor standar, kualitas RPP baru mencapai 87,7\% dari kualitas yang diharapkan. Dengan demikian, dapat dikatakan bahwa kulitas RPP yang disusun oleh para guru yang sudah sertifikasi dan mendapatkan tunjangan profesi masih belum optimal.

\section{Tabel 1. Distribusi Frekuensi Hasil Penilaian Kepala Madrasah/Sekolah terhadap Dokumen RPP yang Disusun Guru}

\begin{tabular}{cccc}
\hline No. & Nilai & Frekuensi & $\begin{array}{c}\text { Nilai } x \\
\text { Frekuensi }\end{array}$ \\
\hline 1. & 40 & 2 & 80 \\
2. & 38 & 1 & 38 \\
3. & 37 & 2 & 74 \\
4. & 36 & 2 & 72 \\
5. & 34 & 1 & 34 \\
6. & 33 & 1 & 33 \\
7. & 32 & 3 & 96 \\
8. & 29 & 1 & 29 \\
& & 13 & 456 \\
\hline
\end{tabular}

\section{Pembahasan}

Berdasarkan data hasil kuesioner yang dipaparkan di atas, diketahui bahwa rata-rata kinerja guru pasca sertifikasi, baik secara keseluruhan, maupun dilihat dari indikator perencanaan pembelajaran, pelaksanaan pembelajaran, penilaian pembelajaran, dan pengembangan profesi, menunjukkan kategori sedang, bahkan masih ada sebagian guru yang menunjukkan kinerja dalam kategori rendah. Artinya, kinerja guru setelah lulus sertifikasi dan mendapat tunjangan profesi masih berada di bawah standar minimum kinerja. Dengan demikian, dapat dikatakan bahwa pelaksanaan program sertifikasi yang digelontorkan pemerintah dengan dana yang tidak sedikit tidak membuat kinerja para guru menjadi optimal.

Hal ini juga didukung oleh hasil wawancara dan hasil telaah dokumen. Hasil wawancara dengan kepala madrasah/sekolah menunjukkan bahwa sebagian besar kepala madrasah/ sekolah menilai kinerja guru yang sudah lulus sertifikasi sudah lebih baik dibandingkan dengan sebelumnya, namun tidak satupun dari mereka yang menilai kinerja guru sudah mencapai kinerja yang optimal atau mencapai standar kinerja yang berlaku, bahkan ada yang menilainya hanya mendekati standar kinerja. Hasil telaah dokumen menunjukkan bahwa kualitas RPP yang disusun oleh guru baru mencapau 87,7\% dari kualitas yang diharapkan. Dengan demikian, dapat dikatakan bahwa kualitas RPP yang disusun oleh para guru yang sudah sertifikasi dan mendapatkan tunjangan profesi masih belum optimal. Penilaian terhadap tidak adanya peningkatan kinerja guru pasca sertifikasi jelas terlihat dari hasil wawancara dengan salah satu kepala MAN di Kota Palembang berikut.

\begin{abstract}
"Saya tidak melihat adanya perbedaan kinerja yang jelas antara guru yang sudah lulus sertifikasi dengan yang belum. Bisa dikatakan, tidak adanya jaminan bahwa yang lulus sertifikasi itu kinerjanya lebih baik, apalagi jika lulus melalui jalur portofolio" (Wawancara, 25 Agustus 2010).
\end{abstract}

Ada berbagai faktor yang menyebabkan belum optimalnya kinerja guru pasca sertifikasi. Dari hasil wawancara diketahui bahwa diantara faktor penghambatnya adalah: kurangnya sarana prasarana pendukung dan masih rendahnya kemampuan guru, sedang faktor pendukungnya adalah kerjasama yang baik antara guru dan kepala madrasah/sekolah, adanya supervisi yang dilakukan baik oleh kepala madrasah/ sekolah maupun pengawas, serta adanya kegiatan KKG, penataran, dan lain-lain yang diadakan oleh Kemendiknas maupun Kemenag. Faktor yang terpenting adalah rendahnya kemampuan guru, terutama guru yang lulus melalui jalur portofolio. Karenanya, salah seorang responden kepala madrasah/sekolah menyarankan agar diadakan pelatihan juga bagi yang lulus sertifikasi melalui jalur potofolio (Wawancara, 25 Agustus 2010).

Selanjutnya, dilihat dari perbedaan kinerja antara guru madrasah dan guru PAI di sekolah umum, antara guru di lingkungan 
perkotaan dan guru di pedesaan, dan antara guru yang lulus sertifikasi melalui jalur portofolio dan jalur PLPG, semuanya tidak ditemukan perbedaan yang signifikan, meskipun perbedaan yang nampak dari skor rata-rata kinerja mereka tetap ada. Dengan demikian, dapat dikatakan bahwa berbagai faktor luar, baik tempat tugas, lingkungan sosial budaya, maupun pelatihan yang diperoleh guru tidak cukup mempengaruhi peningkatan kinerja guru. Akan tetapi faktor keinginan untuk berkembang dari guru sendiri, itulah yang terpenting. Menurut salah seorang kepala SDN di Kota Palembang, peningkatan kinerja guru yang sudah sertifikasi lebih karena guru yang bersangkutan sendirilah yang selalu berusaha untuk berbuat lebih baik dalam mengajar (Wawancara, 4 September 2010). Dengan demikian, jika guru kurang berupaya meningkatkan kinerjanya sendiri, maka peningkatan kinerja tidak mungkin dicapai.

Hasil penelitian ini sejalan dengan pendapat Burhanuddin (2001:272) yang menyatakan bahwa ada lima faktor yang dapat mempengaruhi kinerja guru selaku individu, yakni:

- Kemampuan. Penguasaan terhadap kompetensi kerja mutlak diperlukan guna mencapai sasaran kerja. Kemampuan guru dalam hal ini mampu menguasai empat kompetensi dasar sebagaimana dipersyaratkan UndangUndang.

- Motivasi, yaitu pemberian suatu insentif yang bisa menarik keinginan seseorang untuk melaksanakan sesuatu. Motivasi tidak terlepas dari kebutuhan dan dorongan yang ada dalam diri seseorang yang menjadi penggerak, energi dan pengaruh segenap tindak manusia.

- Dukungan yang diterima, merupakan menifestasi kebutuhan sosial terhadap tugas dan tanggung jawab yang telah dilaksanakan.

- Keberadaan pekerjaan yang mereka lakukan. Pada dasarnya pekerjaan yang guru lakukan harus dapat diakui sehingga memberikan dampak positif dan menjadi motivasi bagi guru. Sebaik apapun tugas yang dilaksanakan, jika tidak memperoleh pengakuan maka tidak dapat memberikan manfaat baik bagi individu pelaksana tugas maupun orang lain, terutama dalam satuan organisasi kerja.

- Hubungan mereka dengan organisasi. Hubungan antara guru dengan organisasi harus berjalan secara kondusif. Hubungan yang kondusif dapat diciptakan apabila masingmasing anggota organisasi mengetahui batas-batas tugas, tanggung jawab dan wewenangnya dalam menjalankan tugas.

Mangkunegara (2001:87) menyoroti faktor internal yang mempengaruhi kinerja, yaitu: (1) Faktor kemampuan; secara psikologis kemampuan (ability) pegawai terdiri dari kemampuan potensi (IQ) dan kemampuan realita (pendidikan). Oleh karena itu pegawai perlu ditempatkan pada pekerjaan yang sesuai dengan keahliannya; (2) Faktor motivasi; motivasi terbentuk dari sikap (attiude) seorang pegawai dalam menghadapi situasi kerja. Motivasi merupakan kondisi yang menggerakkan diri pegawai terarah untuk mencapai tujuan kerja. Sikap mental merupakan kondisi mental yang mendorong seseorang untuk berusaha mencapai potensi kerja secara maksimal. David McClelland (Mangkunegara, 2001:68), berpendapat bahwa, "Ada hubungan yang positif antara motif berprestasi dengan pencapaian kerja". Motif berprestasi adalah suatu dorongan dalam diri seseorang untuk melakukan suatu kegiatan atau tugas dengan sebaik-baiknya agar mampu mencapai prestasi kerja (kinerja) dengan predikat terpuji.

Hasil penelitian ini konsisten dengan penelitian yang pernah dilakukan oleh penelitian yang dilakukan oleh peneliti lain. Penelitian Survei yang dilakukan oleh Ridwan El Hariri (2011) berjudul "Dampak Sertifikasi Terhadap Kinerja Guru di Jawa Barat" menunjukkan bahwa sertifikasi memiliki pengaruh yang rendah terhadap kinerja guru. Hal ini tampak dari hasil analisis perbandingan kinerja guru sebelum dan setelah lulus sertifikasi di mana rata-rata kinerja guru pasca sertifikasi justru mengalami penurunan dibandingkan sebelum sertifikasi.

Begitupun penelitian Cindy Sir Annajiyyah (2011) yang berjudul "Studi Komparatif Kinerja Guru yang Belum Sertifikasi dengan 
Guru yang Sudah Sertifikasi di SMP Negeri SeKomisariat Karawang Kota". Hasil penelitian tersebut menyimpulkan bahwa secara statistik tidak terdapat perbedaan yang signifikan antara kinerja guru yang belum sertifikasi dengan guru sudah sertifikasi di SMP Negeri Se-Komisariat Karawang Kota.

Penelitian korelasional yang dilakukan oleh Kusdinarsah (2011) juga menjunjukkan hasil serupa. Penelitian yang berjudul Pengaruh Sertifikasi Guru terhadap Peningkatan Kemampuan Profesional Mengajar Guru PKn (Studi Korelasi Terhadap Guru PKn SMA Se-Kabupaten Bandung) ini menunjukkan bahwa terdapat hubungan yang signifikan antara sertifikasi guru dengan peningkatan kemampuan profesional mengajar guru PKn. Hasil perhitungan menunjukan bahwa sertifikasi guru memberikan kontribusi sebesar 47,19\% terhadap peningkatan kemampuan mengajar guru PKn pada taraf kepercayaan $95 \%$.

\section{PENUTUP}

Berdasarkan hasil analisis kuantitatif terhadap data kuesioner dapat disimpulkan bahwa: (1) Kinerja guru pasca sertifikasi, baik secara keseluruhan, maupun dilihat dari indikator perencanaan pembelajaran, pelaksanaan pembelajaran, penilaian pembelajaran, dan pengembangan profesi, rata-rata masih dibawah standar minimum kinerja, serta (2) Tidak terdapat perbedaan kinerja setelah memperoleh tunjangan profesional melalui program sertifikasi guru baik antara guru madrasah dan guru PAIS di sekolah umum, antara guru yang tinggal di lingkungan perkotaan dan guru yang tinggal di pedesaan, dan antara guru yang yang lulus sertifikasi melalui jalur portofolio dan guru yang lulus melalui jalur PLPG.

Berdasarkan hasil analisis kualitatif terhadap data hasil wawancara dan telaah dokumen dapat ditarik kesimpulan bahwa: (1) kinerja guru yang sudah lulus sertifikasi belum mencapai kinerja yang optimal atau mencapai standar kinerja yang berlaku. Berdasarkan hasil telaah dokumen, kualitas RPP yang disusun oleh para guru yang sudah sertifikasi dan mendapatkan tunjangan profesi masih belum opti- mal; (2) faktor penghambat peningkatan kinerja guru diantaranya adalah: kurangnya sarana prasarana pendukung dan kemampuan guru yang masih rendah; dan (3) faktor pendukungnya diantaranya adalah: adanya kemauan untuk maju sehingga mendorong guru tersebut berbuat lebih baik, kerjasama yang baik antara guru dan kepala madrasah/sekolah, dan adanya kegiatan KKG, penataran, dan lain-lain yang diadakan oleh Kemendiknas maupun Kemenag.

\section{UCAPAN TERIMA KASIH}

Dalam penulisan artikel ini penulis menyampaikan ucapan terima kasih yang tak terhingga kepada pihak-pihak yang membantu dalam menyelesaikan penelitian ini, khususnya kepada:

- Balai Penelitian dan Pengembangan Agama Jakarta yang telah menjadi sponsor yang mendanai pelaksanaan penelitian ini.

- Dr. Musnur Hery, M.Ag (dosen Fakultas Tarbiyah IAIN Raden Fatah) dan Drs. H. Amin Thaib, M.Pd. (peneliti senior pada Balai Penelitian dan Pengembangan Agama Jakarta) yang telah bersedia menjadi pembahas pada saat seminar hasil penelitian.

- Pengelola jurnal Cakrawala Pendidikan yang telah berkenan memuat artikel hasil penelitian ini.

- Secara khusus penulis menyampaikan terima kasih kepada keluarga tercinta yang telah memberikan dorongan dan bantuan serta pengertian yang besar kepada penulis dalam pelaksanaan penelitian dan penyelesaian artikel ini.

- Semua pihak yang tidak dapat disebutkan satu persatu, yang telah memberikan bantuan dalam penulisan artikel ini.

\section{DAFTAR PUSTAKA}

Alamsyah, Andi R. dan Muh. Azis Muslim. 2006. Model Penilaian Kinerja Wakil Rakyat. Jakarta: DIA FISIP UI.

Annajiyyah, Cindy S. 2011. Studi Komparatif Kinerja Guru yang Belum Sertifikasi dengan Guru yang Sudah Sertifikasi di SMP Negeri Se-Komisariat Karawang 
Kota. http://repository.upi.edu/skripsiview.php?no_skripsi=10119). Diunduh 26 Januari 2012.

Bernardin, H. John dan Joyce E.A. Russel. 2002. Human Resource Management: An Experimental Approach. Singapore: Mc Graw Hill Inc.

Burhanuddin. 2001. Analisis Administrasi Manajemen dan Kepemimpinan Pendidikan. Jakarta: Bumi Aksara.

Creswell, John W. 2008. Educational Research, Planning, Conducting, and Evaluating Quantitative and Qualitative Research. USA: Prentice Hall.

Ditjen Dikdasmen. 2000. Pembinaan Profesionalisme Guru. Jakarta: Depdiknas.

El Hariri, Ridwan. 2010. Dampak Sertifikasi terhadap Kinerja Guru di Jawa Barat. http://penelitian.lppm.upi.edu/detil/1229/ DAMPAK-SERTIFIKASI-TERHADAP -KINERJA-GURU-DI-JAWA-BARAT. Diunduh 26 Januari 2012.

Kusdinarsah. 2011. Pengaruh Sertifikasi Guru terhadap Peningkatan Kemampuan Profesional Mengajar Guru PKn (Studi Korelasi Terhadap Guru PKn SMA Se-Kabupaten Bandung). http://repository.upi.edu/skripsiview.php?no_skripsi=6670. diunduh tanggal 26 Januari 2012.

Mangkunegara, Anwar P. 2001. Manajemen Sumber Daya Manusia Perusahaan, Bandung: Remaja Rosdakarya.
Schacter, John. Teacher Performance-Based Accountability: Why What and How. http://www.mff.org/pubs/performance_as sessment.pdf. Diunduh 12 Februari 2010.

Sedarmayanti. 1995. Sumber Daya Manusia dan Produktivitas Kerja. Bandung: Mandor Maju.

Simamora, Henry. 2000. Manajemen Sumber Daya Manusia. Yogyakarta: Bagian Penerbitan STIE YKPN.

Simanjuntak, Payaman J. 2005. Manajemen dan Evaluasi Kinerja. Jakarta: Penerbit Lembaga Fakultas Ekonomi Universitas Indonesia.

Son, 2009. "Sertifikasi Guru Tidak Tepat Sasaran", Kompas, 13 November. http://edukasi.kompas.com/read/2009/11/13/07 473414/Sertifikasi.Guru.Tidak.Tepat.Sas aran. Diunduh 3 Agustus 2010.

Usman, Mohammad U. 2006. Menjadi Guru Profesional. Bandung: PT. Remaja Rosdakarya.

Prawirosentono, Suyadi, 1999. Manajemen Sumber Daya Manusia Kebijakan Kinerja Karyawan: Kiat Membangun Organisasi Kompetitif Menjelang Perdagangan Bebas Dunia. Yogyakarta: BPFE. 